\title{
Correction to: Prevalence of wheezing and atopic diseases in Austrian schoolchildren in conjunction with urban, rural or farm residence
}

\author{
Elisabeth Horak for GABRIEL Study Group - Bernhard Morass for GABRIEL Study Group - Hanno UImer for \\ GABRIEL Study Group · Jon Genuneit for GABRIEL Study Group · Charlotte Braun-Fahrländer for GABRIEL Study \\ Group · Erika von Mutius for GABRIEL Study Group
}

Published online: 26 August 2019

(C) Springer-Verlag GmbH Austria, part of Springer Nature 2019

\section{Correction:}

Wien Klin Wochenschr 2014

https://doi.org/10.1007/s00508-014-0571-z

The disclosure needs to additionally mention the following:

Erika von Mutius is listed as inventor on the following patents:

- Publication number EP 1411977: Composition containing bacterial antigens used for the prophylaxis and the treatment of allergic diseases.

- Publication number EP 1637147: Stable dust extract for allergy protection
- Publication number EP 1964570: Pharmaceutical compound to protect against allergies and inflammatory diseases

Erika von Mutius is listed as inventor and has received royalties on the following patent:

- Publication number EP 2361632: Specific environmental bacteria for the protection from and/or the treatment of allergic, chronic inflammatory and/or autoimmune disorders.
The online version of the original article can be found under https://doi.org/10.1007/s00508-014-0571-z.

E. Horak, M.D. P.D. $(\bowtie)$

Department of Pediatrics, Division of Pediatric Cardiology and Pulmonology, Innsbruck Medical University,

Anichstr. 35, 6020 Innsbruck, Austria

Elisabeth.Horak@uki.at 